\title{
Synergism Effect of the Essential Oil from Ocimum basilicum var. Maria Bonita and Its Major Components with Fluconazole and Its Influence on Ergosterol Biosynthesis
}

\author{
Nathalia N. R. Cardoso, ${ }^{1,2}$ Celuta S. Alviano, ${ }^{1,2}$ Arie F. Blank, ${ }^{3}$ Maria Teresa V. Romanos, \\ Beatriz B. Fonseca, ${ }^{4}$ Sonia Rozental, ${ }^{4}$ Igor A. Rodrigues, ${ }^{5}$ and Daniela S. Alviano ${ }^{1}$ \\ ${ }^{1}$ Departamento de Microbiologia Geral, Instituto de Microbiologia Paulo de Góes, Universidade Federal do Rio de Janeiro, \\ 21941-902 Rio de Janeiro, RJ, Brazil \\ ${ }^{2}$ Programa de Pós-Graduação em Biotecnologia Vegetal (PBV), Decania, CCS, Universidade Federal do Rio de Janeiro, \\ 21941-902 Rio de Janeiro, RJ, Brazil \\ ${ }^{3}$ Departamento de Engenharia Agronômica, Universidade Federal de Sergipe, 49100-000 São Cristóvão, SE, Brazil \\ ${ }^{4}$ Instituto de Biofísica Carlos Chagas Filho, Universidade Federal do Rio de Janeiro, 21941-902 Rio de Janeiro, RJ, Brazil \\ ${ }^{5}$ Departamento de Produtos Naturais e Alimentos, Faculdade de Farmácia, Universidade Federal do Rio de Janeiro, \\ 21941-902 Rio de Janeiro, RJ, Brazil
}

Correspondence should be addressed to Daniela S. Alviano; danialviano@micro.ufrj.br

Received 21 December 2015; Accepted 6 April 2016

Academic Editor: José L. Ríos

Copyright (c) 2016 Nathalia N. R. Cardoso et al. This is an open access article distributed under the Creative Commons Attribution License, which permits unrestricted use, distribution, and reproduction in any medium, provided the original work is properly cited.

\begin{abstract}
The aim of this study was to evaluate the activity of the EO and its major components of Ocimum basilicum var. Maria Bonita, a genetically improved cultivar, against the fluconazole sensitive and resistant strains of Candida albicans and Cryptococcus neoformans. Geraniol presented better results than the EO, with a low MIC $(76 \mu \mathrm{g} / \mathrm{mL}$ against C. neoformans and $152 \mu \mathrm{g} / \mathrm{mL}$ against both Candida strains). The combination of EO, linalool, or geraniol with fluconazole enhanced their antifungal activity, especially against the resistant strain (MIC reduced to 156,197 , and $38 \mu \mathrm{g} / \mathrm{mL}$, resp.). The ergosterol assay showed that subinhibitory concentrations of the substances were able to reduce the amount of sterol extracted. The substances tested were able to reduce the capsule size which suggests they have an important mechanism of action. Transmission electron microscopy demonstrated cell wall destruction of $C$. neoformans after treatment with subinhibitory concentrations. In C. albicans ultrastructure alterations such as irregularities in the membrane, presence of vesicles, and cell wall thickening were observed. The biofilm formation was inhibited in both C. albicans strains at MIC and twice MIC. These results provide further support for the use of O. basilicum EO and its major components as a potential source of antifungal agents.
\end{abstract}

\section{Introduction}

Candidiasis is a fungal disease that affects a large number of individuals. Skin or mucous membranes are the most common sites of infection, especially the mouth and vagina [1]. However, the disease may evolve from a superficial infection to systemic infection, especially in immunocompromised individuals $[2,3]$. The most frequent etiological agent of candidiasis is Candida albicans. This pathogen is an opportunistic fungus able to form biofilms, which are of major clinical concern. Moreover, fungi communities structured in extracellular polysaccharide matrices possess increased resistance to antifungal therapy $[3,4]$.

C. neoformans is responsible for cryptococcosis, a disease affecting the central nervous system and having high levels of mortality. C. neoformans has several well-characterized virulence factors such as capsular polysaccharide, sialic acids, and the production of mannitol and melanin. The former is considered the most important virulence factor of $C$. neoformans and therefore the most studied. The capsule 
contributes to the microorganism virulence through multiple mechanisms, including antiphagocytic properties and adverse effects on the host immune system $[5,6]$.

Despite current antifungal therapies, cryptococcal and candidal infections show unpleasant high mortality rates in immunocompromised individuals. A study conducted by Park et al. [7] revealed that cryptococcal meningitis was responsible for 624,700 deaths after 3 months of infection. A previous case-control study indicated that mortality attributable to invasive Candida infection was about $19-24 \%$ among hospitalized patients [8]. Factors that contribute to this scenario include a limited antifungal arsenal, diverse side effects, and drug resistant strains [1].

Essential oils (EOs) and plant extracts are commonly used in traditional medicine by indigenous populations worldwide $[9,10]$. EOs are complex mixtures of volatile (terpenes, aliphatic aldehydes, alcohols, and esters) and nonvolatile components (hydrocarbons, fatty acids, sterols, carotenoids, waxes, coumarins, and flavonoids) produced by aromatic plants as secondary metabolites [11]. Various studies have attributed different biological activities to EOs such as antiviral, antigiardial, antispasmodic, carminative, analgesic, healing, expectorant, antiseptic, respiratory tract, and antiinflammatory activities [12-16].

Ocimum basilicum (Lamiaceae) is found in tropical and subtropical regions of Asia, Africa, Central America, and South America [17]. Popularly known as basil, O. basilicum is a culinary and medicinal herb widely used in folk medicine to combat headaches, coughs, intestinal worms, and kidney disorders and as an antispasmodic agent [18]. The antimicrobial activity of basil EO has been reported to be predominantly associated with its major components, linalool and methyl chavicol [19]. The antimicrobial activity of these components and other monoterpenes has been reported in the literature against various microorganisms, including protozoans, bacteria, and fungi [20-23]. The purpose of this study was to investigate the antifungal activity of the essential oil and its major components (linalool and geraniol) from a genetically improved $O$. basilicum cultivar (O. basilicum var. Maria Bonita) against C. neoformans and fluconazole (FLC) sensitive and resistant $C$. albicans strains.

\section{Material and Methods}

2.1. Chemicals. Fluconazole (FLC), resazurin, 2,3-bis(2-methoxy-4-nitro-5sulfofenil)-5-[(phenylamino)carbonyl]-2Htetrazolium hydroxide (XTT), 3-(4,5-dimethylthiazol-2-yl)2,5-diphenyltetrazolium bromide (MTT), linalool (97\%), and geraniol (98\%) standards were obtained from Sigma-Aldrich (USA) and stored according to the supplier's instructions. All solvents used were of spectroscopic grade from Tedia (Fairfield, OH, USA).

2.2. Plant Material and Essential Oil. Ocimum basilicum L. var. "Maria Bonita" is a genetically improved cultivar with a high content of linalool. O. basilicum EO was provided by the Federal University of Sergipe, where a voucher specimen was deposited (register number 13162). EO was extracted from the leaves by hydrodistillation using a Clevenger apparatus. The chemical composition of the EO was analyzed by a GC-MS and previously published by Da Costa et al. [24] and linalool was identified as the major component of the EO (75.22\%), followed by geraniol (14.66\%).

2.3. Microorganisms. Cryptococcus neoformans T-444 serotype A was provided by Universidade Federal de São Paulo (UNIFESP). C. albicans FLC resistant strain was isolated from the oral cavity of a pediatric patient infected with HIV and C. albicans (7173 serotype B) and was kindly provided by Hospital Evandro Chagas/FIOCRUZ/RJ. The microorganisms were maintained in Sabouraud dextrose agar for $48 \mathrm{~h}$ at room temperature.

2.4. Macrophage Culture. Macrophage cell line RAW 264.7 was purchased from the Rio de Janeiro cell bank. Cells were grown in Dulbecco's Modified Eagle Medium (DMEM) supplemented with $2 \mathrm{mM}$ L-glutamine, $50 \mu \mathrm{g} / \mathrm{mL}$ gentamicin, and $2.5 \mu \mathrm{g} / \mathrm{mL}$ Fungizone ${ }^{\mathrm{TM}}$, plus $10 \%$ of heat-inactivated fetal bovine serum (FBS) and maintained at $37^{\circ} \mathrm{C}$ in an atmosphere of $5 \% \mathrm{CO}_{2}$.

2.5. Evaluation of Inhibitory Concentrations. The minimum inhibitory concentration (MIC) was determined using the microdilution broth method according to CLSI M27-A [25]. First, the O. basilicum EO and linalool and geraniol standards were serially diluted into 96 -well plates in duplicates. Then $100 \mu \mathrm{L}$ of cell suspension $\left(10^{3}\right.$ yeast $\left./ \mathrm{mL}\right)$ was added to each well and the plate was incubated at room temperature for 24 or $48 \mathrm{~h}$. Positive controls were prepared using yeast inoculated growth medium (untreated cells). Pure medium was used for the negative controls. Growth inhibition was confirmed after the addition of $30 \mu \mathrm{L}$ of resazurin solution ( $5 \mathrm{mg} / 100 \mathrm{~mL}$ of phosphate buffer saline, PBS; pH 7.2) and further incubation at $37^{\circ} \mathrm{C}$ for $3 \mathrm{~h}$. FLC was used as the antimicrobial standard drug. MIC was defined as the lowest concentration of the EO, linalool, and geraniol that completely invalidated the microorganism growth.

2.6. Synergism Assay with the Antifungal Standard Drug FLC. The synergistic effect of the EO, linalool, and geraniol on FLC antifungal activity was performed as previously described by Zore et al. [23], with slight modifications. FLC and $\mathrm{O}$. basilicum EO or its major components (linalool and geraniol) were combined at concentrations lower than their individual MIC values into 96-well microplates. Each plate was inoculated with $10^{3}$ cells $/ \mathrm{mL}$ and incubated at room temperature for $24 \mathrm{~h}$ or $48 \mathrm{~h}$, according to the requirements of the microorganisms. The results were based on visual growth, which were confirmed with the addition of resazurin as described above. Fractional inhibitory concentrations (FICs) for each substance and in their combination with FLC were calculated as follows:

$$
\begin{aligned}
& \text { FIC }_{\text {index }} \\
& =\frac{\text { concentration that inhibits } 100 \% \text { of growth in combination }}{\text { concentration that inhibits } 100 \% \text { of growth alone }} .
\end{aligned}
$$


The FIC $_{\text {index }}$ was calculated by adding both FIC values. FIC $_{\text {index }}$ values $<0.5$ and $>4.0$ have synergistic and antagonistic interactions, respectively [26].

2.7. Determination of the Amount of Ergosterol. Sterol extraction was performed as previously reported by ArthingtonSkaggs et al. [27], with a slight modification. A single C. albicans or C. neoformans colony from an overnight Sabouraud dextrose agar plate culture was inoculated in $50 \mathrm{~mL}$ of Sabouraud dextrose broth containing different concentrations of the EO, linalool, and geraniol $(625,395$, and $38 \mu \mathrm{g} / \mathrm{mL}$ for C. neoformans and 625, 395, and $76 \mu \mathrm{g} / \mathrm{mL}$ for C. albicans, resp.). C. albicans and C. neoformans cultures were incubated at $37^{\circ} \mathrm{C}$ for 18 and $24 \mathrm{~h}$, respectively, with shaking. The cells were harvested by centrifugation and washed with sterile water. The wet weight of the cell pellet was determined. Three milliliters of $25 \%$ alcoholic potassium hydroxide solution ( $25 \mathrm{~g}$ of $\mathrm{KOH}$ and $36 \mathrm{~mL}$ of sterile distilled water, brought to $100 \mathrm{~mL}$ with $100 \%$ ethanol) was added and mixed by vortex for $1 \mathrm{~min}$. Cell suspensions were incubated in a water bath at $85^{\circ} \mathrm{C}$ for $1 \mathrm{~h}$. After the incubation period, the tubes were cooled at room temperature. The extraction of the sterols was carried out by the addition of $1 \mathrm{~mL}$ of sterile distilled water and $3 \mathrm{~mL}$ of cyclohexane and then mixing by vortex for $3 \mathrm{~min}$. The cyclohexane layer was transferred to a clean borosilicate glass tube. Then, $200 \mu \mathrm{L}$ aliquot of sterol extract was diluted fivefold in $100 \%$ ethanol and scanned spectrophotometrically between 200 and $300 \mathrm{~nm}$ (DU 530 Life Science UV/Visible Spectrophotometer, Beckman Coulter) [27].

Both 24(28)-dehydroergosterol (24(28) DHE, a late sterol pathway intermediate) and ergosterol absorb at $281.5 \mathrm{~nm}$, but only 24(28) DHE shows an absorption spectrum at $230 \mathrm{~nm}$. Ergosterol content was calculated as a percentage of the wet weight of the cells using the following equations: \% ergosterol $+\%$ 24(28) $\mathrm{DHE}=\left[\left(A_{281.5} / 290\right) \times F\right] /$ pellet weight; \% 24(28) $\mathrm{DHE}=\left[\left(A_{230} / 518\right) \times F\right] /$ pellet weight, and \% ergosterol $=$ [\% ergosterol + \% 24(28) DHE] - \% 24(28) DHE, where $F$ is the factor for dilution in ethanol and 290 and 518 are the $E$ values determined for crystalline ergosterol and 24(28) DHE, respectively [28].

2.8. Antibiofilm Formation Activity. The effects of the $O$. basilicum EO, linalool, and geraniol against $C$. albicans biofilm formation were evaluated. In order to assure better yeast adhesion, 96-well microplates were pretreated with $100 \mu \mathrm{L}$ of fetal bovine serum (FBS) for 30 minutes at $37^{\circ} \mathrm{C}$. The microplates were washed with PBS and then $100 \mu \mathrm{L}$ of $C$. albicans suspension $\left(1 \times 10^{7}\right.$ cells/mL) in YNB (yeast nitrogen base) broth, supplemented with $2 \%$ glucose, $\mathrm{pH} 7.0$, was inoculated into the wells and incubated at $37^{\circ} \mathrm{C}$ for $90 \mathrm{~min}$. Nonadherent cells were removed by washing the microplates twice with PBS, and then $100 \mu \mathrm{L}$ of different concentrations of the EO, linalool, and geraniol was added to the wells (final concentrations at one- and twofold MIC). After $48 \mathrm{~h}$ incubation at $35^{\circ} \mathrm{C}$, the medium was removed and the biofilm was washed with PBS [29]. The untreated biofilms were used as positive control.
Biofilm quantification was made by the cellular reduction of salt XTT. First, $150 \mu \mathrm{L}$ of XTT-menadione solution $(12.5 \mu \mathrm{g} / \mathrm{mL}$ of XTT $+0.17 \mu \mathrm{g} / \mathrm{mL}$ of menadione) in PBS was added to each well, and then the microplates were incubated for $2 \mathrm{~h}$ at $35^{\circ} \mathrm{C}$ in the dark. After the incubation period, $100 \mu \mathrm{L}$ from each well was transferred to another 96-well microplate and the optical density was determined at $475 \mathrm{~nm}$ (SpectraMax M5, Molecular Devices, USA) [29].

2.9. Transmission Electron Microscopy. C. neoformans, FLC sensitive, and resistant $C$. albicans strains were treated with subinhibitory concentrations of the EO $(625 \mu \mathrm{g} / \mathrm{mL}$ for all microorganisms) and geraniol $(38 \mu \mathrm{g} / \mathrm{mL}$ for C. neoformans and $76 \mu \mathrm{g} / \mathrm{mL}$ for both C. albicans strains) for $48 \mathrm{~h}$ at $37^{\circ} \mathrm{C}$.

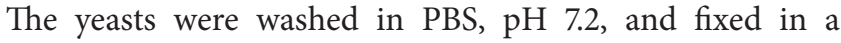
solution of $2.5 \%$ glutaraldehyde and $4 \%$ formaldehyde in $0.1 \mathrm{M}$ cacodylate buffer, $\mathrm{pH} 7.2$, for $1 \mathrm{~h}$ at room temperature. Next, the yeasts were postfixed for $2 \mathrm{~h}$ in $1 \%$ osmium tetroxide containing $1.25 \%$ potassium ferrocyanide and $5 \mathrm{mM} \mathrm{CaCl}_{2}$ in cacodylate buffer, $\mathrm{pH}$ 7.2. The yeasts were then washed in the same buffer, dehydrated with increasing ethanol concentrations $(30,50,70,90$, and $100 \%$ and ultradry ethanol), with the cells remaining in each concentration for $30 \mathrm{~min}$, and then embedded in Spurr resin. Ultrathin sections were stained with uranyl acetate and lead citrate, and images were obtained using a Zeiss 900 electron microscope equipped with a CCD Camera (mega view III model, Soft Image System, Germany). The images were processed with iTEM software (Soft Image System, Germany).

2.10. C. neoformans Capsule Size. C. neoformans was incubated for $48 \mathrm{~h}$ at $35^{\circ} \mathrm{C}$ in the presence of subinhibitory concentrations of EO, linalool, and geraniol $(625,395$, and $38 \mu \mathrm{g} / \mathrm{mL}$, resp.). After $48 \mathrm{~h}$, an aliquot was removed and fixed with a formaldehyde solution (10\% formaldehyde in PBS) to measure capsule sizes. Slides were prepared for measurements with a drop of cells and a drop of India ink dye to enable capsule visualization. The images were obtained using a Zeiss Axioplan microscope. Measurements were performed using ImageJ software considering the distance between the cell wall and the outer edge of the capsule. Each cell was measured in four different regions to obtain the average capsule size. Thirty cells were analyzed for each condition.

2.11. Cytotoxicity. Cytotoxicity was assessed via MTT reduction as previously described [30]. Several concentrations of O. basilicum $\mathrm{EO}$, linalool, and geraniol ranging from 5000 to $310 \mu \mathrm{g} / \mathrm{mL}, 3156$ to $197 \mu \mathrm{g} / \mathrm{mL}$, and 612 to $38.3 \mu \mathrm{g} / \mathrm{mL}$, respectively, were placed in contact with the RAW cell cultures and incubated at $37^{\circ} \mathrm{C}$ for $24 \mathrm{~h}$. Next, $10 \mu \mathrm{L}$ of MTT solution was added to cell cultures and incubated for $3 \mathrm{~h}$ at $37^{\circ} \mathrm{C}$. The formazan crystals formed were solubilized by adding $100 \mu \mathrm{L}$ of dimethylsulfoxide (DMSO). The absorbance was determined at $490 \mathrm{~nm}$ in an automatic spectrophotometer (ELx800TMBio-TeK Instruments, Inc.). The 50\% cytotoxic concentration (CC50) was defined as the compound concentration which caused a $50 \%$ reduction in the number of viable cells. 
TABLE 1: Evaluation of interaction resulting from the combination of the substances tested by determining the FIC $_{\text {index }}$ using the checkerboard technique.

\begin{tabular}{|c|c|c|c|c|c|c|c|c|c|c|c|c|c|c|c|c|}
\hline \multirow{2}{*}{ Strain } & \multicolumn{4}{|c|}{$\operatorname{MIC}(\mu \mathrm{g} / \mathrm{mL})$} & \multicolumn{12}{|c|}{ MIC in combination $(\mu \mathrm{g} / \mathrm{mL})$} \\
\hline & $\mathrm{EO}$ & $\mathrm{L}^{\mathrm{a}}$ & $\mathrm{G}^{\mathrm{b}}$ & $\mathrm{FLC}^{\mathrm{c}}$ & FLC & $\mathrm{EO}$ & $\begin{array}{l}\text { FIC }^{\mathrm{d}} \\
\text { index }\end{array}$ & FLC & $\mathrm{L}$ & $\begin{array}{c}\text { FIC } \\
\text { index }\end{array}$ & FLC & G & $\begin{array}{c}\text { FIC } \\
\text { index }\end{array}$ & $\mathrm{L}$ & G & $\begin{array}{c}\text { FIC } \\
\text { index }\end{array}$ \\
\hline C. neoformans & 1250 & 790 & 76 & 31.25 & 4.14 & 625 & $\begin{array}{c}0.633 \\
(\mathrm{I})^{\mathrm{e}}\end{array}$ & 8.054 & 197 & $\begin{array}{l}0.5077 \\
\text { (I) }\end{array}$ & 4.14 & 19 & $\begin{array}{c}0.3826 \\
(S)\end{array}$ & 111 & 19 & $\begin{array}{c}0.3905 \\
(\mathrm{~S})\end{array}$ \\
\hline C. albicans resistant & 1250 & 1580 & 152 & 500 & 1.01 & 156 & $\begin{array}{c}0.127 \\
(S)^{\mathrm{f}}\end{array}$ & 2.02 & 197 & $\begin{array}{c}0.134 \\
(\mathrm{~S})\end{array}$ & 1.04 & 38 & $\begin{array}{c}0.252 \\
(\mathrm{~S})\end{array}$ & 397 & 4.8 & $\begin{array}{c}0.284 \\
(\mathrm{~S})\end{array}$ \\
\hline C. albicans sensitive & 1250 & 790 & 152 & 0.975 & 0.259 & 312 & $\begin{array}{c}0.51 \\
(\mathrm{I})\end{array}$ & 0.065 & 395 & $\begin{array}{c}0.57 \\
(\mathrm{I})\end{array}$ & 0.259 & 38 & $\begin{array}{c}0.51 \\
(\mathrm{I})\end{array}$ & 105 & 38 & $\begin{array}{c}0.38 \\
(\mathrm{~S})\end{array}$ \\
\hline
\end{tabular}

${ }^{\mathrm{a}} \mathrm{L}$ : linalool; ${ }^{\mathrm{b}} \mathrm{G}$ : geraniol; ${ }^{\mathrm{c}}$ FLC: fluconazole; ${ }^{\mathrm{d}}$ FIC index: fractional inhibitory concentration index; ${ }^{\mathrm{e}} \mathrm{I}$ : indifferent; ${ }^{\mathrm{f}} \mathrm{S}$ : synergist.

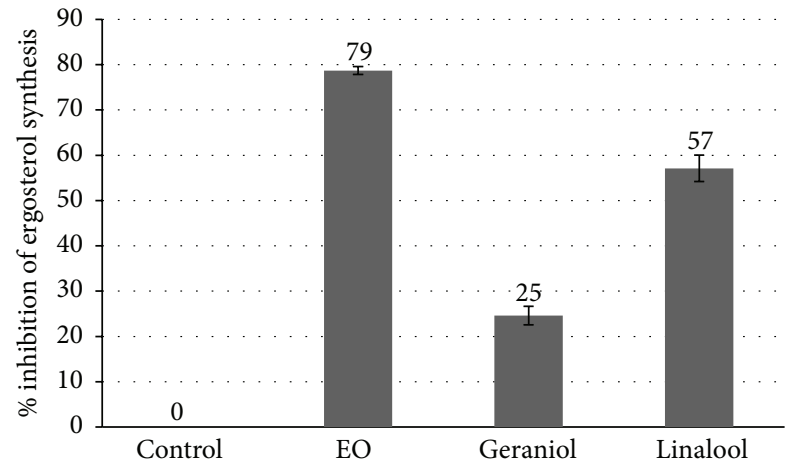

(a)

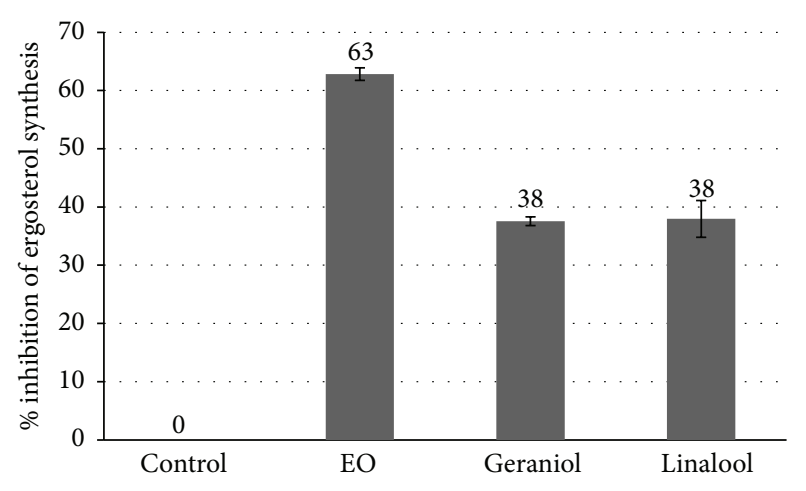

(b)

FIGURE 1: Effect of $625 \mu \mathrm{g} / \mathrm{mL}$ of EO, $395 \mu \mathrm{g} / \mathrm{mL}$ of linalool, and $38 \mu \mathrm{g} / \mathrm{mL}$ of geraniol on the inhibition of ergosterol synthesis in C. neoformans (a) and the effect of $625 \mu \mathrm{g} / \mathrm{mL}$ of EO, $395 \mu \mathrm{g} / \mathrm{mL}$ of linalool, and $76 \mu \mathrm{g} / \mathrm{mL}$ of geraniol on the C. albicans sensitive strain (b). The results represent the mean \pm standard error of two independent experiments in triplicate.

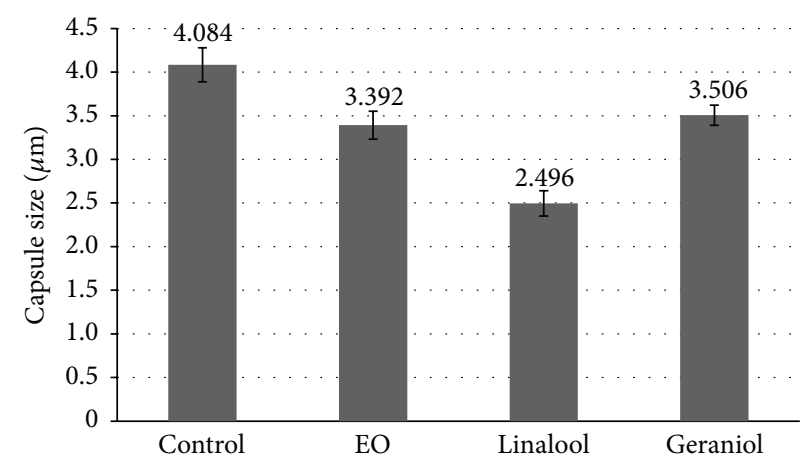

FIGURE 2: Effect of $625 \mu \mathrm{g} / \mathrm{mL}$ EO, $395 \mu \mathrm{g} / \mathrm{mL}$ linalool, and $38 \mu \mathrm{g} / \mathrm{mL}$ geraniol on the capsule size.

\section{Results and Discussion}

The results of minimum inhibitory concentrations are shown in Table 1. The MIC values found for the EO against C. neoformans, C. albicans sensitive, and C. albicans resistant strain were similar $(1250 \mu \mathrm{g} / \mathrm{mL})$. Geraniol was the most effective compound against all the strains tested $(76 \mu \mathrm{g} / \mathrm{mL}$ against C. neoformans and $152 \mu \mathrm{g} / \mathrm{mL}$ against the two C. albicans strains tested). However, different results were observed with linalool. The MIC for linalool was $790 \mu \mathrm{g} / \mathrm{mL}$ against $C$. neoformans and C. albicans sensitive and $1580 \mu \mathrm{g} / \mathrm{mL}$ against the C. albicans fluconazole resistant strain. Our preliminary results with MIC corroborate with reports in the literature that show antimicrobial properties of extracts and essential oils of other natural products and their major components [31-37].

These results encouraged us to evaluate the combination of EO, linalool, and geraniol with a standard drug. Previous works have reported that the combination of different antifungal agents or the combination of natural products and standard drugs could reduce their separate MIC values. Liu et al. [38] showed that the combination of FLC and glabridin, an isoflavan isolated from Glycyrrhiza glabra, reduced the MIC values of $C$. neoformans, indicating a synergistic effect. Faria 


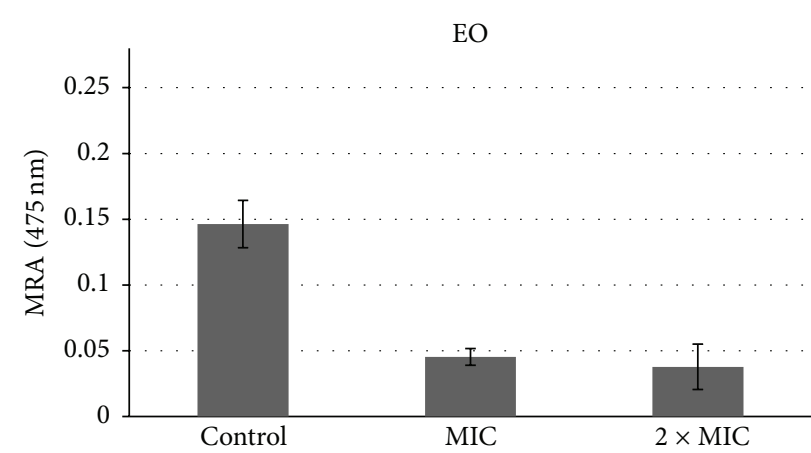

(a)

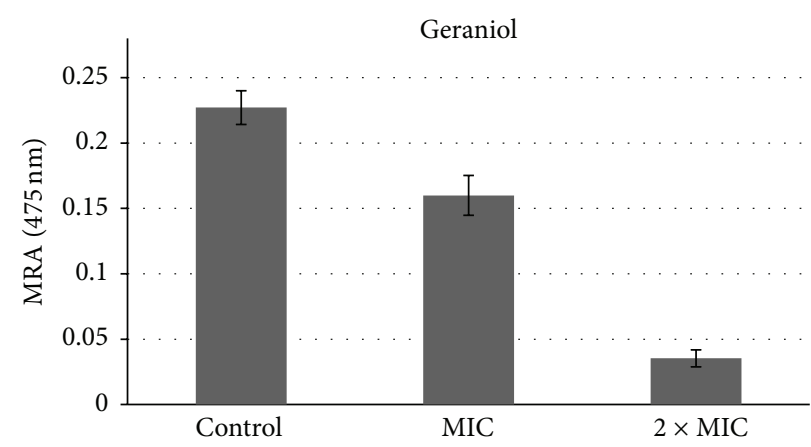

(c)

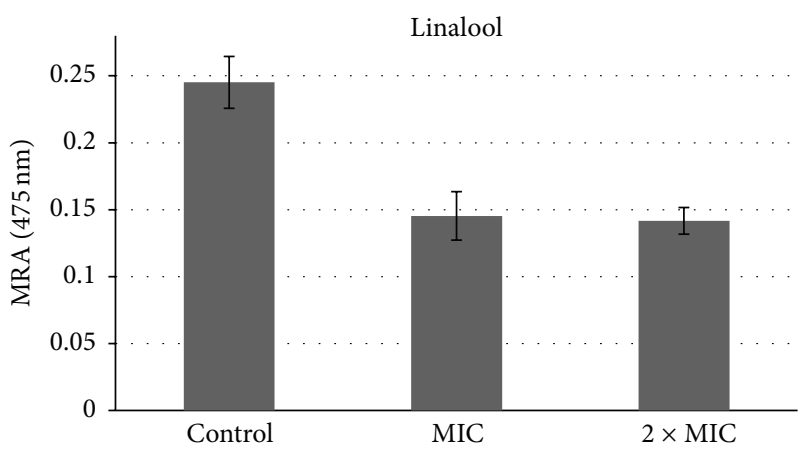

(e)

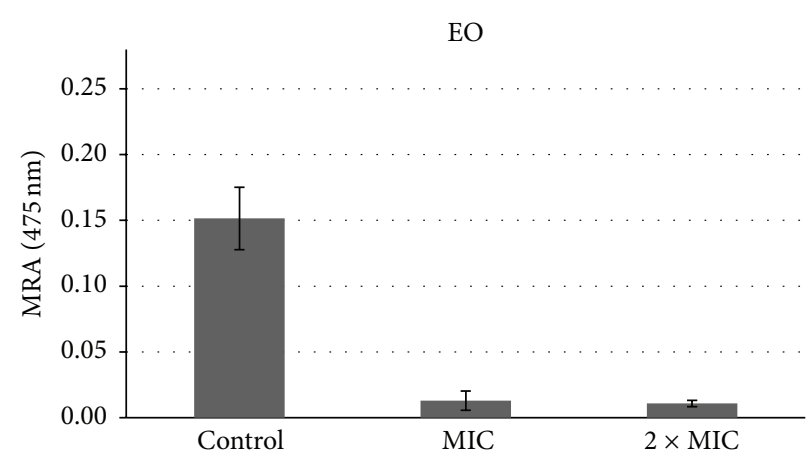

(b)

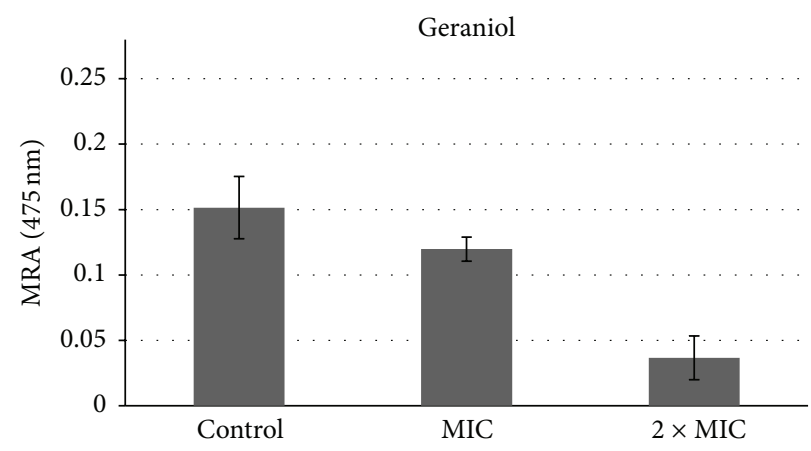

(d)

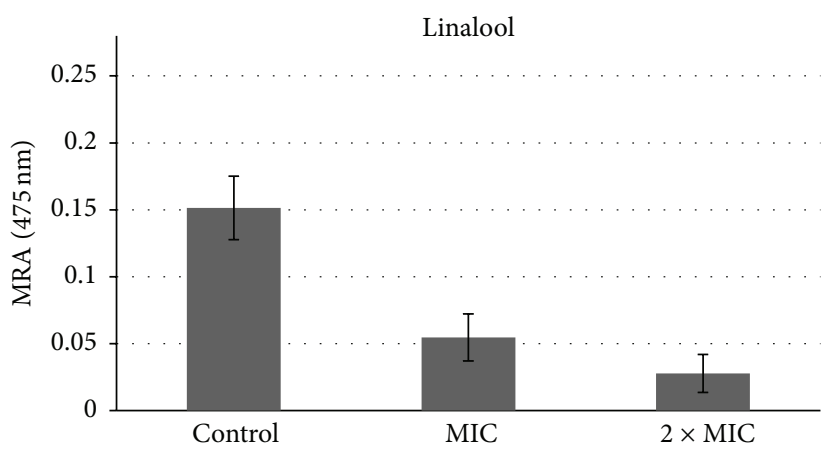

(f)

FIGURE 3: Effect of O. basilicum EO, geraniol, and linalool standards on the mitochondrial reducing activity (MRA) of biofilms formed by C. albicans sensitive ( $\mathrm{a}, \mathrm{c}, \mathrm{e}$ ) and $\mathrm{C}$. albicans fluconazole resistant (b, d, and f) treated with one- and twofold MIC concentrations. The results represent the mean \pm standard error of two independent experiments in triplicate. Values over the bars refer to the percentage of inhibition of biofilm viability.

et al. [39] found a synergistic effect in the combination of 2,5-dihydroxybenzaldehyde and FLC against C. neoformans. In this work, we evaluate the effect of EO and its major components (geraniol and linalool) with the reference drug FLC and the combination of the two major components against $C$. neoformans. All the combinations tested produced $\mathrm{FIC}_{\text {index }}$ values ranging from 0.3826 to 0.6326 . This showed that all these combinations reduced the MIC values. The synergistic effect was observed in the combination of FLC and geraniol, reducing their MIC from 31.25 to $4.14 \mu \mathrm{g} / \mathrm{mL}$ and 76 to $19 \mu \mathrm{g} / \mathrm{mL}$, respectively, and in the combination of linalool with geraniol, reducing their MIC values from 790 to $111 \mu \mathrm{g} / \mathrm{mL}$ and 76 to $19 \mu \mathrm{g} / \mathrm{mL}$, respectively. When FLC was combined with $197 \mu \mathrm{g} / \mathrm{mL}$ linalool and $625 \mu \mathrm{g} / \mathrm{mL}$ EO, their
MIC values were reduced from 31.25 to 8.054 and $4.14 \mu \mathrm{g} / \mathrm{mL}$ in the respective combinations (Table 1). It is important to note that, in combination, the needed concentrations of the two major components together to completely eradicate $C$. neoformans were very low. No combination of $O$. basilicum $\mathrm{EO}$ and commercial antifungal agents against $C$. neoformans was found in the literature consulted.

For the Candida albicans strains all the combinations tested produced FIC $_{\text {index }}$ values ranging from 0.127 to 0.57 . Although all the combinations reduced the MIC values in at least one of the paired substances, we did not observe any synergistic effect in the combinations of natural components with FLC against C. albicans sensitive. However, a synergistic effect was observed in the combination of linalool with 

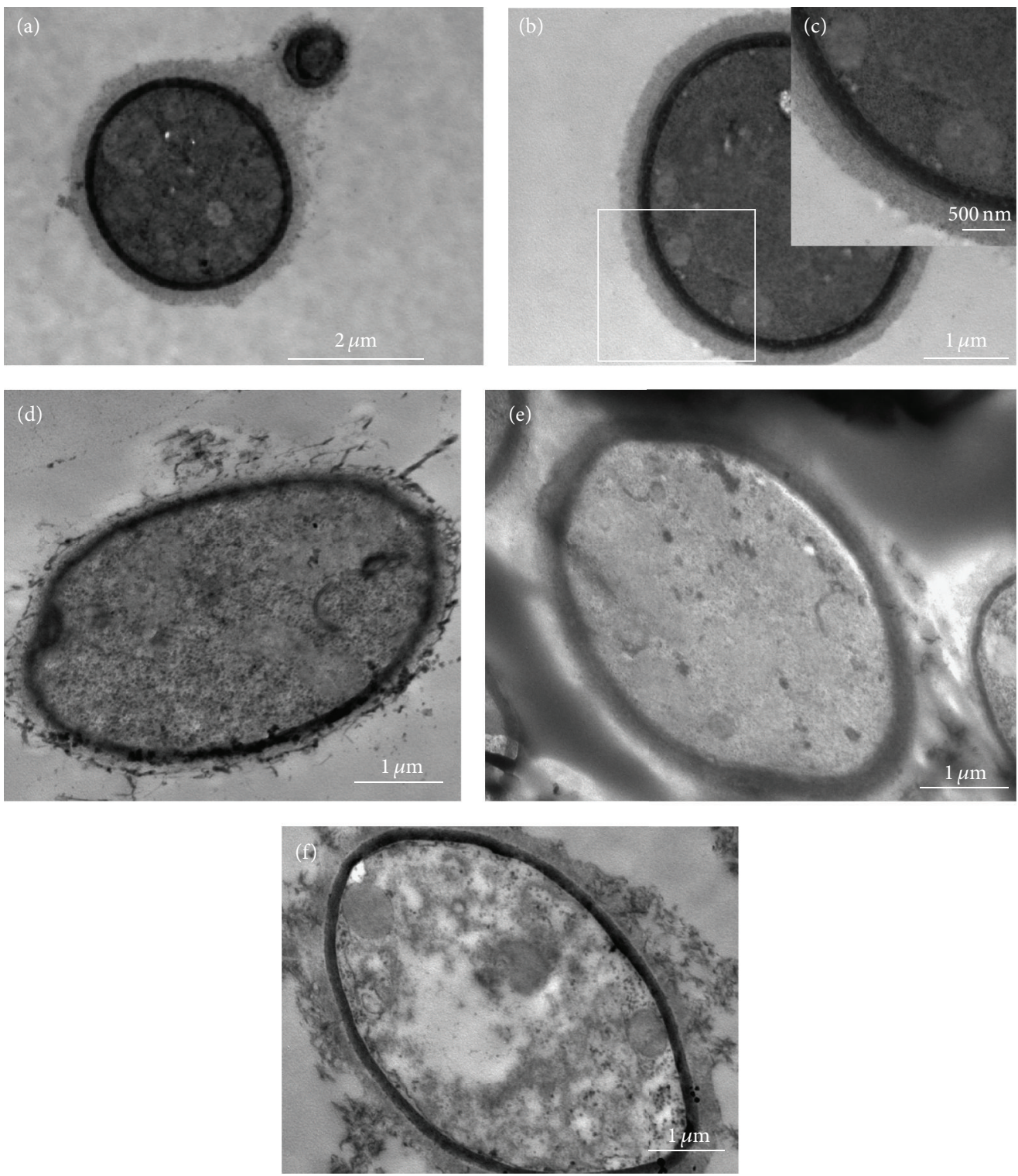

FIGURE 4: Transmission electron microscopy of C. neoformans T444 strain treated with $625 \mu \mathrm{g} / \mathrm{mL}$ of EO, $38 \mu \mathrm{g} / \mathrm{mL}$ of geraniol, and $395 \mu \mathrm{g} / \mathrm{mL}$ of linalool for $48 \mathrm{~h}$ at $37^{\circ} \mathrm{C}$. Untreated cells (control) showed good preservation of cell wall and membrane and the final of budding (a-c). The cells treated with $625 \mu \mathrm{g} / \mathrm{mL}$ of EO (d), $38 \mu \mathrm{g} / \mathrm{mL}$ of geraniol, (e) and $395 \mu \mathrm{g} / \mathrm{mL}$ of linalool (f) showed a disruption of the fungal capsule structure.

geraniol, reducing their MIC values from 790 to $105 \mu \mathrm{g} / \mathrm{mL}$ and 152 to $38 \mu \mathrm{g} / \mathrm{mL}$, respectively. Furthermore, all combinations tested presented synergistic effect against $C$. albicans resistant. When FLC was combined with EO $156 \mu \mathrm{g} / \mathrm{mL}$, its MIC value was reduced from 500 to $1.01 \mu \mathrm{g} / \mathrm{mL}$. The combination of FLC with $197 \mu \mathrm{g} / \mathrm{mL}$ linalool and $38 \mu \mathrm{g} / \mathrm{mL}$ geraniol reduced its MIC value from 500 to $2.02 \mu \mathrm{g} / \mathrm{mL}$ and to $1.04 \mu \mathrm{g} / \mathrm{mL}$, respectively. This is a significant result because when the high concentrations of the standard drugs are reduced the collateral effects are also reduced. Moreover, the combination of linalool and geraniol caused complete cellular inhibition at reduced MICs of $4.8 \mu \mathrm{g} / \mathrm{mL}$ and $397 \mu \mathrm{g} / \mathrm{mL}$ for geraniol and linalool, respectively (Table 1). These results corroborate with previously reported results that show the synergistic effect of geraniol and FLC against C. albicans [22]. However, when compared with our study, a higher concentration of geraniol $(140 \mu \mathrm{g} / \mathrm{mL})$ was necessary to reduce the MIC value of FLC from 64 to $2 \mu \mathrm{g} / \mathrm{mL}$.

In order to investigate the mechanisms of action of EO, linalool, and geraniol, we analyzed the inhibition of ergosterol synthesis. Ergosterol is an important sterol presented in the yeast cell membrane that controls membrane fluidity and integrity, and it is an important target for some antifungals [40-42]. The treatment of C. neoformans with EO $(625 \mu \mathrm{g} / \mathrm{mL})$, linalool $(395 \mu \mathrm{g} / \mathrm{mL})$, and geraniol $(38 \mu \mathrm{g} / \mathrm{mL})$ results in an inhibition of 79,57 , and $25 \%$ of ergosterol synthesis, respectively (Figure 1(a)). Even in subinhibitory concentrations, the substances tested were able to reduce the 


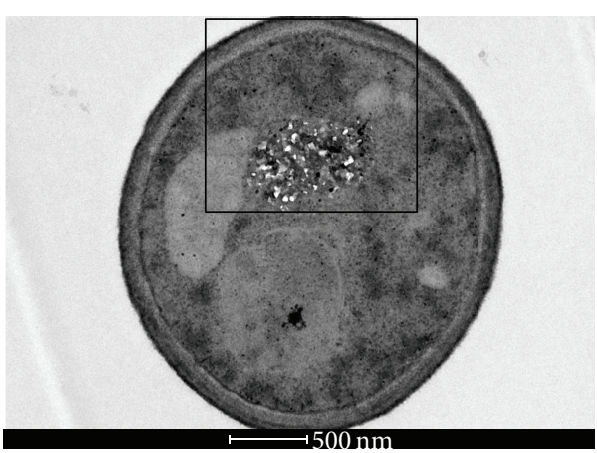

(a)

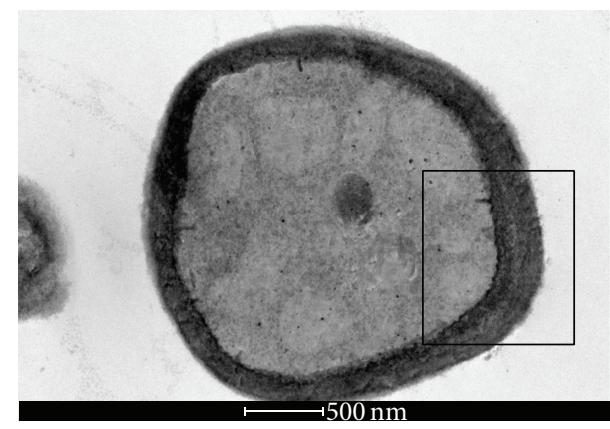

(c)

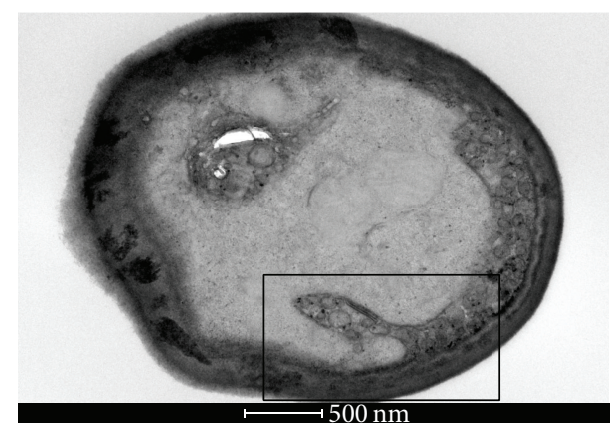

(e)

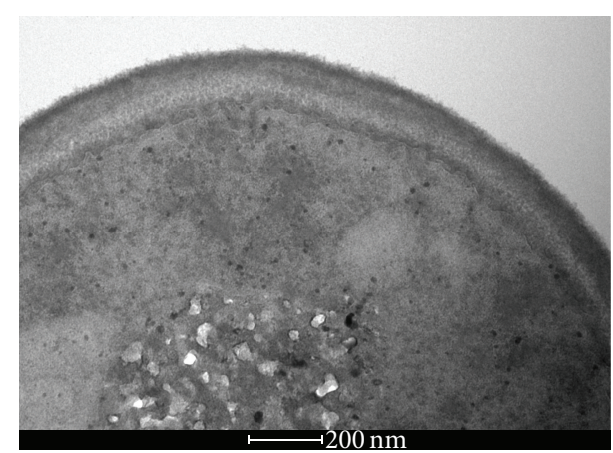

(b)

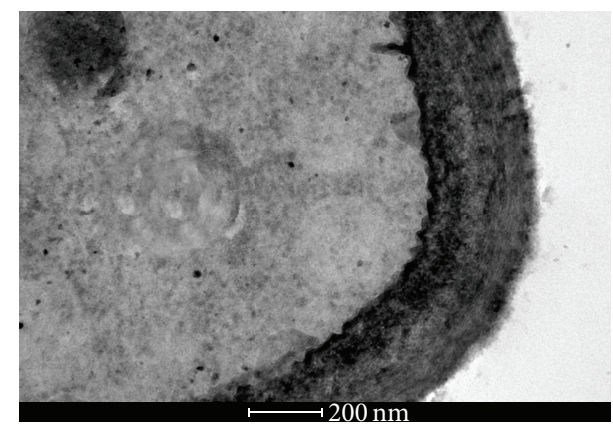

(d)

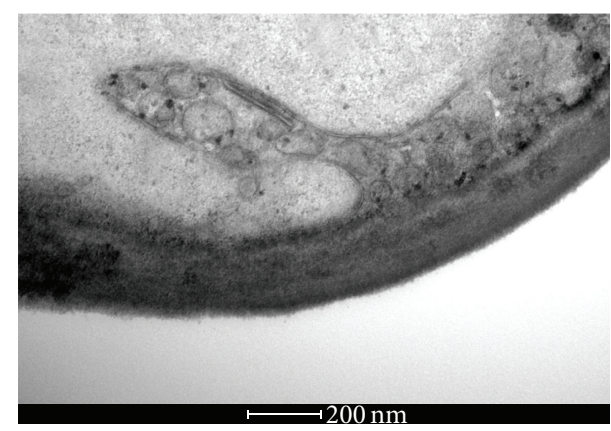

(f)

FIGURE 5: Transmission electron microscopy of C. albicans fluconazole sensitive strain treated with $625 \mu \mathrm{g} / \mathrm{mL}$ of EO and $76 \mu \mathrm{g} / \mathrm{mL}$ of geraniol for $48 \mathrm{~h}$ at $37^{\circ} \mathrm{C}$. The control (untreated) C. albicans sensitive strain cells showed good preservation of cell wall and membrane (a and b). Cells treated with $625 \mu \mathrm{g} / \mathrm{mL}$ of EO presented cell wall thickening ( $c$ and d) and the treatment with $76 \mu \mathrm{g} / \mathrm{mL}$ of geraniol led to the appearance of cell membrane invaginations presenting some vesicles and the thickening of the cell wall (e and $\mathrm{f}$ ).

ergosterol content. This is an indication that they might act in the ergosterol biosynthesis pathway, especially the EO and linalool.

The treatment of $C$. albicans sensitive with $\mathrm{EO}$ $(625 \mu \mathrm{g} / \mathrm{mL})$, linalool $(395 \mu \mathrm{g} / \mathrm{mL})$, and geraniol $(76 \mu \mathrm{g} / \mathrm{mL})$ resulted in an inhibition of 63,38 , and $38 \%$ of ergosterol synthesis, respectively. A similar effect was obtained with $C$. albicans resistant (Figure 1(b)). These data corroborate with those reported by Khan et al. In that study, the treatment with $O$. sanctum essential oil and linalool was also able to decrease ergosterol synthesis in C. albicans [43]. However, in another study, geraniol and linalool were not effective in reducing the ergosterol content in C. albicans, even at higher concentrations ( $4 \mathrm{mg} / \mathrm{mL}$ and $8 \mathrm{mg} / \mathrm{mL}$, resp.) [44].
Another mechanism of action analyzed in this study was the ability of the studied components to reduce the capsule size of $C$. neoformans. The capsule is the major virulence factor of $C$. neoformans and it is an important target of study [45]. In the sub-MIC concentrations tested, linalool showed the highest activity in reducing the capsule size, followed by $\mathrm{EO}$, and geraniol was the least active (Figure 2). The presence of capsules can alter the susceptibility of antimicrobial drugs; therefore, finding natural products that reduce capsule size is extremely important. The results here suggest that the three substances tested can reduce the capsule size; and therefore they might be used with other antimicrobial drugs to reduce the concentration needed and consequently its collateral effects. Vitale et al. tested the activity of antifungal 


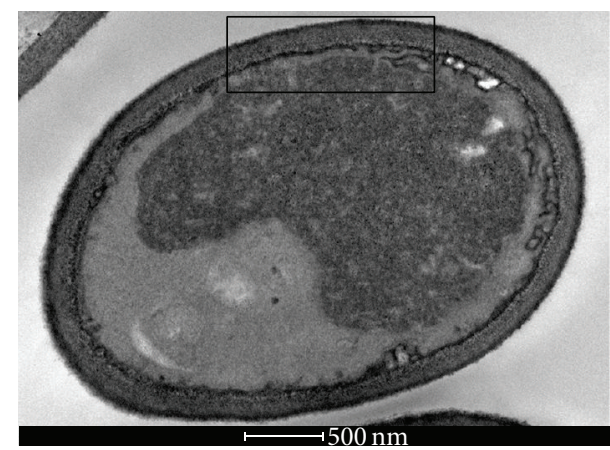

(a)

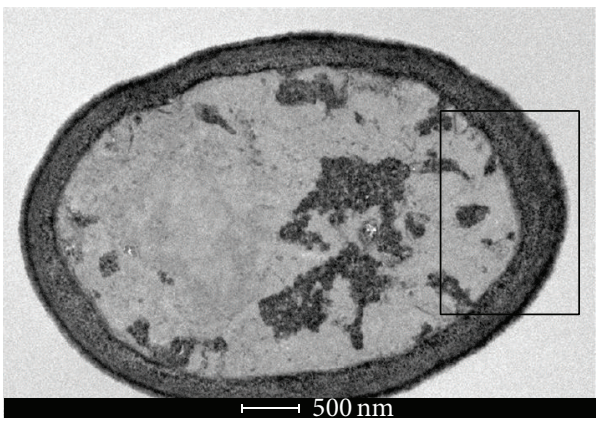

(c)

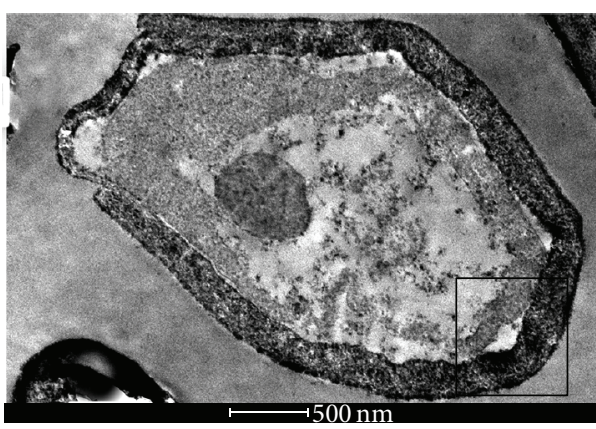

(e)

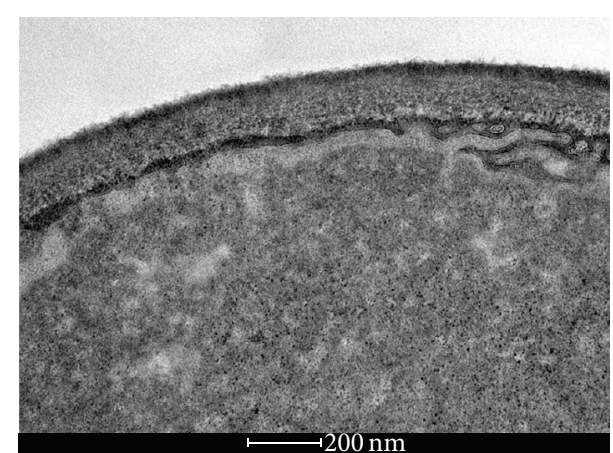

(b)

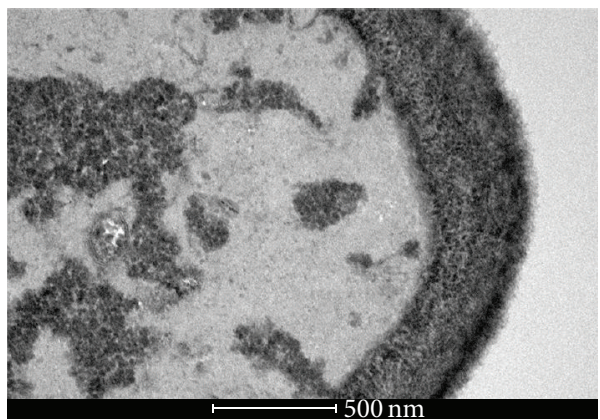

(d)

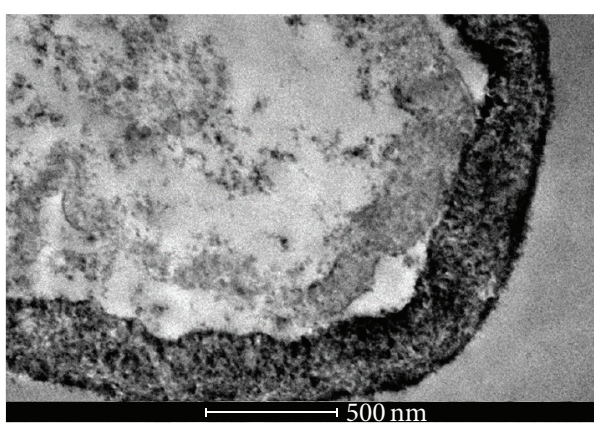

(f)

Figure 6: Transmission electron microscopy of C. albicans fluconazole resistant strain treated with $625 \mu \mathrm{g} / \mathrm{mL}$ of EO and $76 \mu \mathrm{g} / \mathrm{mL}$ of geraniol for $48 \mathrm{~h}$ at $37^{\circ} \mathrm{C}$. Control cells showed good preservation of the membrane, cell wall, and small vesicles near the membrane (a and b). Yeasts treated with subinhibitory concentrations of the essential oil and geraniol showed cell wall thickening and irregularities in the membrane (c and d). Cells treated with subinhibitory concentration of geraniol presented cell wall thickening and irregularities in cell membrane, suggesting budding failure ( $\mathrm{e}$ and $\mathrm{f}$ ).

agents against strains of $C$. neoformans with different capsule sizes. They showed that the presence of capsules affects the susceptibility of the yeast to the antimicrobial tested [46].

The activity of the EO, linalool, and geraniol against $C$. albicans biofilm formation was evaluated and the EO was the most effective. At $2 \mathrm{x}$, its MIC value geraniol appears to be more effective against $C$. albicans sensitive biofilm formation than C. albicans resistant. EO showed the highest biofilm inhibitory activity against both $C$. albicans strains at MIC followed by linalool and geraniol, respectively (Figure 3). Alviano et al. demonstrated that the essential oil of Croton cajucara and purified linalool were effective against artificial biofilms of C. albicans [47]. A previous study showed that the essential oil of Boesenbergia pandurata, with a high content of geraniol $(56.68 \%)$ and $2.36 \%$ of linalool, was able to interfere in the initial phases of Candida biofilm formation [48]. Another study showed a strong antimicrobial activity of the essential oil of $O$. americanum L. against the planktonic form of C. albicans but a less pronounced effect on these microorganisms in biofilms [49]. The biofilm inhibitory activities of linalool and geraniol obtained in the present study are consistent with those described by Dalleau et al., who demonstrated that geraniol was the most effective substance against C. albicans biofilm [50].

In order to observe the ultrastructural changes in the C. neoformans strain after treatment with EO, linalool, and geraniol, the treated and untreated cells, grown for $48 \mathrm{~h}$ at $37^{\circ} \mathrm{C}$, were processed for transmission electron microscopy. 


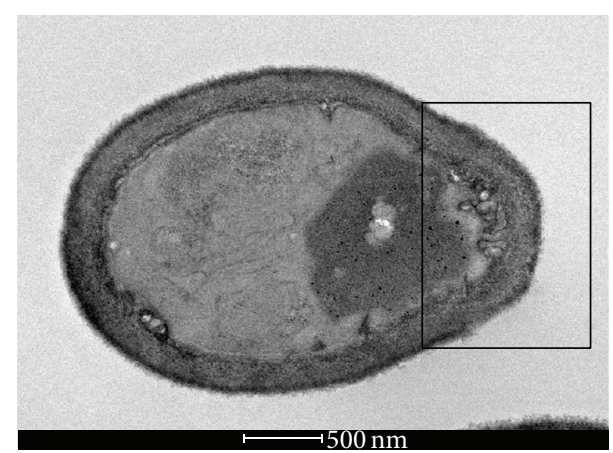

(a)

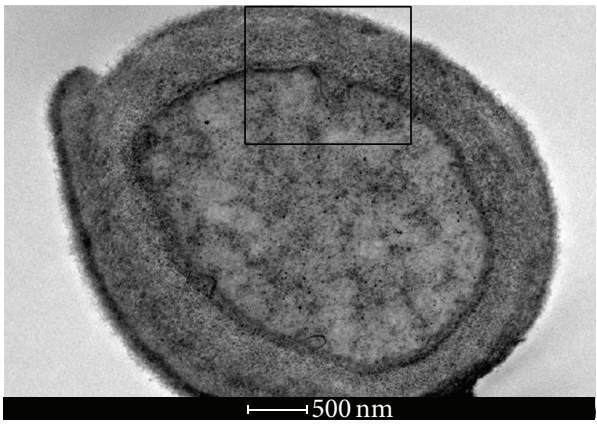

(c)

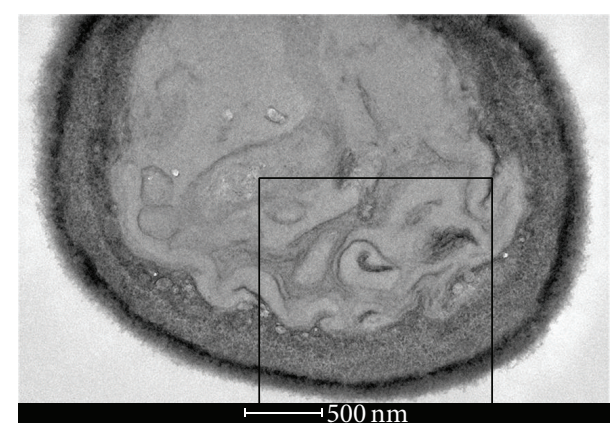

(e)

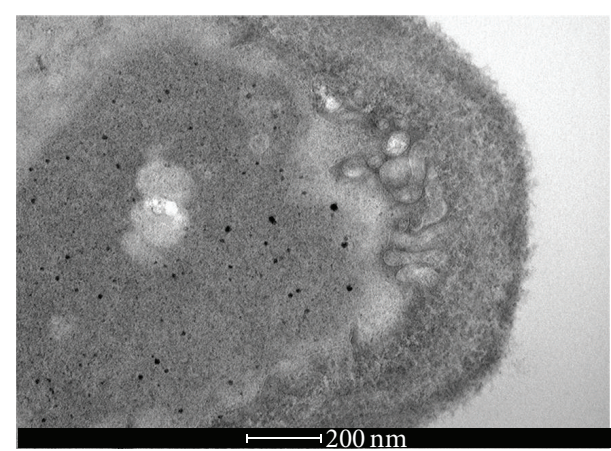

(b)

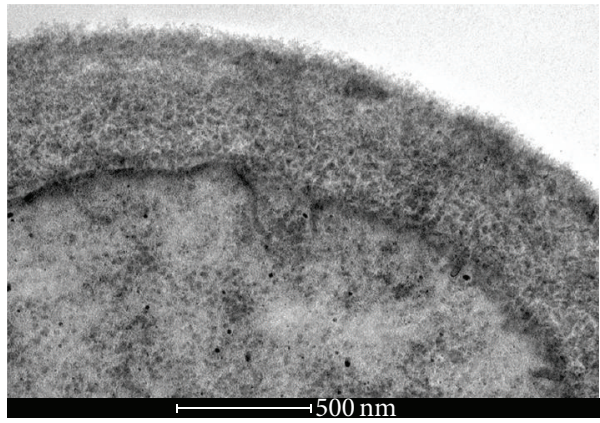

(d)

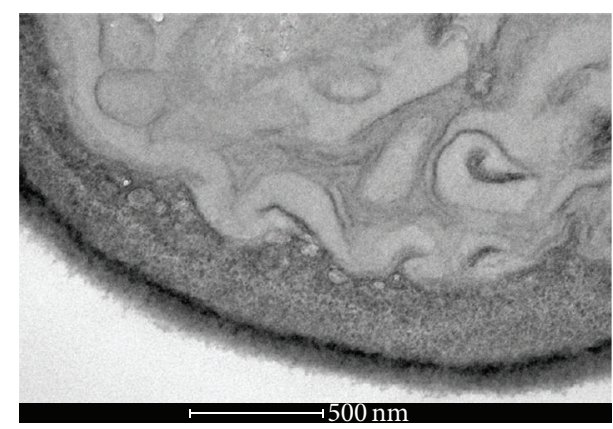

(f)

Figure 7: Transmission electron microscopy of $C$. albicans fluconazole resistant strain treated with FLC alone $(1 \mu \mathrm{g} / \mathrm{mL})$ and combined with geraniol $(38 \mu \mathrm{g} / \mathrm{mL})$ and $\mathrm{EO}(156 \mu \mathrm{g} / \mathrm{mL})$; the latter two trails with FLC exhibited synergistic activity. The treatment with $1 \mu \mathrm{g} / \mathrm{mL}$ of FLC showed cells with irregularity in their membranes and formation of small vesicles in the proximity (a-b). In the treatment with the combination of essential oil $156 \mu \mathrm{g} / \mathrm{mL}$ and FLC $1 \mu \mathrm{g} / \mathrm{mL}$, the cells demonstrated a very thick cell wall and membrane invaginations (c-d). Cells treated with the combination of geraniol $38 \mu \mathrm{g} / \mathrm{mL}$ and FLC $1 \mu \mathrm{g} / \mathrm{mL}$ showed extensive irregularities in the membrane and formation of membrane vesicles in the cytoplasm (e-f).

Untreated cells (control) showed good preservation of cell walls and membrane and the final of budding (Figures 4(a)4(c)). The cells treated with $625 \mu \mathrm{g} / \mathrm{mL}$ of EO (Figure 4(d)), $38 \mu \mathrm{g} / \mathrm{mL}$ of geraniol (Figure $4(\mathrm{e})$ ), and $395 \mu \mathrm{g} / \mathrm{mL}$ of linalool (Figure 4(f)) showed a disruption of the fungal capsule structure.

The control (untreated) C. albicans sensitive strain cells showed good preservation of their cell walls and membranes (Figures 5(a) and 5(b)). Cells treated with $625 \mu \mathrm{g} / \mathrm{mL}$ of EO presented cell wall thickening (Figures 5(c) and 5(d)) and the treatment with $76 \mu \mathrm{g} / \mathrm{mL}$ of geraniol led to the appearance of cell membrane invaginations presenting some vesicles and the thickening of the cell walls (Figures 5(e) and 5(f)). The control cells of $C$. albicans fluconazole resistant strain showed good preservation of the membrane, cell wall, and small vesicles near the membrane (Figures 6(a) and 6(b)). However, yeasts treated with subinhibitory concentrations of $\mathrm{EO}$ and geraniol showed cell wall thickening and irregularities in the membrane (Figures 6(c) and 6(d)). Cells treated with a subinhibitory concentration of geraniol presented cell wall thickening and irregularities in the cell membrane, suggesting budding failure (Figures 6(e) and 6(f)).

In Figure 7, the transmission electron microscopy of C. albicans fluconazole resistant strain treated with FLC alone and in combination with geraniol and EO exhibited a synergistic activity with FLC. FLC treated with $1 \mu \mathrm{g} / \mathrm{mL}$ cells has irregularity in the membrane and formation of small vesicles in the proximity (Figures $7(\mathrm{a})$ and $7(\mathrm{~b})$ ). Treated 
with the combination of essential oil $156 \mu \mathrm{g} / \mathrm{mL}$ and FLU $1 \mu \mathrm{g} / \mathrm{mL}$ cells presented a very thick cell wall and membrane invaginations (Figures $7(\mathrm{c})$ and $7(\mathrm{~d})$ ). Cells treated with the combination of geraniol $38 \mu \mathrm{g} / \mathrm{mL}$ and FLU $1 \mu \mathrm{g} / \mathrm{mL}$ showed large irregularities in the membrane and formation of membrane vesicles in the cytoplasm (Figures 7(e) and 7(f)).

The cytotoxic activities of essential oil, geraniol, and linalool were analyzed on a RAW cell line and showed $\mathrm{CC}_{50}$ at a concentration of $380 \mu \mathrm{g} / \mathrm{mL}$ for geraniol and less than $310 \mu \mathrm{g} / \mathrm{mL}$ and $197 \mu \mathrm{g} / \mathrm{mL}$ (the lowest concentrations evaluated) for essential oil and linalool, respectively. According to this, the MIC values found for geraniol were much lower than the $\mathrm{CC}_{50}$. Using the checkerboard, MIC values of linalool and EO were reduced to 105 and $156 \mu \mathrm{g} / \mathrm{mL}$, respectively, in some combinations, which can minimize the cytotoxic activity of these components.

\section{Conclusions}

In this study we showed that geraniol displayed the highest activity against $C$. neoformans and the strains of $C$. albicans tested and the lowest cytotoxicity, when compared with linalool and the EO The ergosterol inhibition and the synergism showed the potential activity of this natural product and that its combination with standard drugs can be useful against the microorganisms tested. The anticryptococcal activity described here encourages the search for more effective substances of vegetal origin for the treatment of cryptococcosis.

Besides the antifungal activity described here the results support the use of $O$. basilicum essential oil as a folk medicine and open perspectives to find more effective substances from vegetal origin for the treatment of fungal diseases.

\section{Appendix}

See Table 1.

\section{Competing Interests}

The authors declare that they have no competing interests.

\section{Acknowledgments}

The present work was supported by Conselho Nacional de Desenvolvimento Científico e Tecnológico (CNPq), Coordenação de Aperfeiçoamento de Pessoal de Nível Superior (CAPES), Financiadora de Estudos e Projetos (FINEP), Fundação de Amparo a Pesquisa do Estado do Rio de Janeiro (FAPERJ), and Universidade Federal do Rio de Janeiro (UFRJ).

\section{References}

[1] C. G. Pierce and J. L. Lopez-Ribot, "Candidiasis drug discovery and development: new approaches targeting virulence for discovering and identifying new drugs," Expert Opinion on Drug Discovery, vol. 8, no. 9, pp. 1117-1126, 2013.
[2] S. Biswas, P. V. Dijck, and A. Datta, "Environmental sensing and signal transduction pathways regulating morphopathogenic determinants of Candida albicans," Microbiology and Molecular Biology Reviews, vol. 71, no. 2, pp. 348-376, 2007.

[3] S. E. Herwald and C. A. Kumamoto, "Candida albicans niche specialization: features that distinguish biofilm cells from commensal cells," Current Fungal Infection Reports, vol. 8, no. 2, pp. 179-184, 2014.

[4] G. Ramage, R. Rajendran, L. Sherry, and C. Williams, "Fungal biofilm resistance," International Journal of Microbiology, vol. 2012, Article ID 528521, 14 pages, 2012.

[5] T. L. Doering, "How sweet it is! Cell wall biogenesis and polysaccharide capsule formation in Cryptococcus neoformans," Annual Review of Microbiology, vol. 63, pp. 223-247, 2009.

[6] O. Zaragoza, M. L. Rodrigues, M. De Jesus, S. Frases, E. Dadachova, and A. Casadevall, "The capsule of the fungal pathogen Cryptococcus neoformans," Advances in Applied Microbiology, vol. 68, pp. 133-216, 2009.

[7] B. J. Park, K. A. Wannemuehler, B. J. Marston, N. Govender, P. G. Pappas, and T. M. Chiller, "Estimation of the current global burden of cryptococcal meningitis among persons living with HIV/AIDS," AIDS, vol. 23, no. 4, pp. 525-530, 2009.

[8] J. Morgan, M. I. Meltzer, B. D. Plikaytis et al., "Excess mortality, hospital stay, and cost due to candidemia: a case-control study using data from population-based candidemia surveillance," Infection Control and Hospital Epidemiology, vol. 26, no. 6, pp. 540-547, 2005.

[9] A. Gurib-Fakim, "Medicinal plants: traditions of yesterday and drugs of tomorrow," Molecular Aspects of Medicine, vol. 27, no. 1, pp. 1-93, 2006.

[10] S. Zielińska and A. Matkowski, "Phytochemistry and bioactivity of aromatic and medicinal plants from the genus Agastache (Lamiaceae)," Phytochemistry Reviews, vol.13, no. 2, pp. 391-416, 2014.

[11] M. Jalali-Heravi and H. Parastar, "Recent trends in application of multivariate curve resolution approaches for improving gas chromatography-mass spectrometry analysis of essential oils," Talanta, vol. 85, no. 2, pp. 835-849, 2011.

[12] J. Bruneton, Pharmacognosy, Phytochemistry and Medicinal Plants, Intercept, Andover, Mass, USA, 2nd edition, 1999.

[13] N. P. Jones, J. T. Arnason, M. Abou-Zaid, K. Akpagana, P. Sanchez-Vindas, and M. L. Smith, "Antifungal activity of extracts from medicinal plants used by first nations peoples of eastern canada," Journal of Ethnopharmacology, vol. 73, no. 1-2, pp. 191-198, 2000.

[14] D. Lopes-Lutz, D. S. Alviano, C. S. Alviano, and P. P. Kolodziejczyk, "Screening of chemical composition, antimicrobial and antioxidant activities of Artemisia essential oils," Phytochemistry, vol. 69, no. 8, pp. 1732-1738, 2008.

[15] G. B. Melo, R. L. Silva, V. A. Melo et al., "Effect of the aqueous extract of Hyptis pectinata on liver mitochondrial respiration," Phytomedicine, vol. 12, no. 5, pp. 359-362, 2005.

[16] J. L. Ríos and M. C. Recio, "Medicinal plants and antimicrobial activity," Journal of Ethnopharmacology, vol. 100, no. 1-2, pp. 8084, 2005.

[17] Z. Zakaria, R. Aziz, Y. L. Lachimanan, S. Sreenivasan, and X. Rathinam, "Antioxidant activity of Coleus blumei, Orthosiphon stamineus, Ocimum basilicum and Mentha arvensis from lamiaceae family," International Journal of Nursing Education Scholarship, vol. 2, pp. 93-95, 2008. 
[18] S.-J. Lee, K. Umano, T. Shibamoto, and K.-G. Lee, "Identification of volatile components in basil (Ocimum basilicum L.) and thyme leaves (Thymus vulgaris L.) and their antioxidant properties," Food Chemistry, vol. 91, no. 1, pp. 131-137, 2005.

[19] B. Bozin, N. Mimica-Dukic, N. Simin, and G. Anackov, "Characterization of the volatile composition of essential oils of some Lamiaceae spices and the antimicrobial and antioxidant activities of the entire oils," Journal of Agricultural and Food Chemistry, vol. 54, no. 5, pp. 1822-1828, 2006.

[20] I. De Almeida, D. S. Alviano, D. P. Vieira et al., "Antigiardial activity of Ocimum basilicum essential oil," Parasitology Research, vol. 101, no. 2, pp. 443-452, 2007.

[21] R. Kotan, S. Kordali, and A. Cakir, "Screening of antibacterial activities of twenty-one oxygenated monoterpenes," Zeitschrift für Naturforschung C, vol. 62, no. 7-8, pp. 507-513, 2007.

[22] G. B. Zore, A. D. Thakre, V. Rathod, and S. M. Karuppayil, "Evaluation of anti-Candida potential of geranium oil constituents against clinical isolates of Candida albicans differentially sensitive to fluconazole: inhibition of growth, dimorphism and sensitization," Mycoses, vol. 54, no. 4, pp. e99-e109, 2011.

[23] G. B. Zore, A. D. Thakre, S. Jadhav, and S. M. Karuppayil, "Terpenoids inhibit Candida albicans growth by affecting membrane integrity and arrest of cell cycle," Phytomedicine, vol. 18, no. 13, pp. 1181-1190, 2011.

[24] A. S. Da Costa, M. F. Arrigoni-Blank, M. A. A. P. Da Silva et al., "The impact of hybridization on the volatile and sensorial profile of Ocimum basilicum L," The Scientific World Journal, vol. 2014, Article ID 824594, 8 pages, 2014.

[25] Clinical and Laboratory Standards Institutes (CLSI), Methods for Dilution Antimicrobial Susceptibility Tests, Approved Standard, Norms M27-A, CLSI, Wayne, Pa, USA, 4th edition, 2008.

[26] F. C. Odds, "Synergy, antagonism, and what the chequerboard puts between them," Journal of Antimicrobial Chemotherapy, vol. 52, article 1, 2003.

[27] B. A. Arthington-Skaggs, H. Jradi, T. Desai, and C. J. Morrison, "Quantitation of ergosterol content: novel method for determination of fluconazole susceptibility of Candida albicans," Journal of Clinical Microbiology, vol. 37, no. 10, pp. 3332-3337, 1999.

[28] O. N. Breivik and J. L. Owades, "Spectrophotometric semimicrodetermination of ergosterol in yeast," Agricultural and Food Chemistry, vol. 5, no. 5, pp. 360-363, 1957.

[29] B. P. Krom, J. B. Cohen, G. E. McElhaney Feser, and R. L. Cihlar, "Optimized candidal biofilm microtiter assay," Journal of Microbiological Methods, vol. 68, no. 2, pp. 421-423, 2007.

[30] T. Mosmann, "Rapid colorimetric assay for cellular growth and survival: application to proliferation and cytotoxicity assays," Journal of Immunological Methods, vol. 65, no. 1-2, pp. 55-63, 1983.

[31] D. Q. Falcão, E. R. Costa, D. S. Alviano, C. S. Alviano, R. M. Kuster, and F. S. Menezes, "Effect of drying time on the essential oil content of Ocimum basilicum $L$ and its antimicrobial activity," Pharmacologyonline, vol. 1, pp. 1-6, 2008.

[32] R. L. Fabri, E. S. Coimbra, A. C. Almeida et al., "Essential oil of Mitracarpus frigidus as a potent source of bioactive compounds," Anais da Academia Brasileira de Ciências, vol. 84, no. 4, pp. 1073-1080, 2012.

[33] Y. Silva-Belmares, C. Rivas-Morales, E. Viveros-Valdez, M. G. de la Cruz-Galicia, and P. Carranza-Rosales, "Antimicrobial and cytotoxic activities from Jatropha dioica roots," Pakistan Journal of Biological Sciences, vol. 17, no. 5, pp. 748-750, 2014.
[34] N. Chaftar, M. Girardot, N. Quellard et al., "Activity of six essential oils extracted from Tunisian plants against Legionella pneumophila," Chemistry and Biodiversity, vol. 12, no. 10, pp. 1565-1574, 2015.

[35] I. C. Marinas, E. Oprea, M. C. Chifiriuc, I. A. Badea, M. Buleandra, and V. Lazar, "Chemical composition and antipathogenic activity of Artemisia annua essential oil from Romania," Chemistry and Biodiversity, vol. 12, no. 10, pp. 1554-1564, 2015.

[36] E. S. Dezaki, H. Mahmoudvand, F. Sharififar, S. Fallahi, L. Monzote, and F. Ezatkhah, "Chemical composition along with anti-leishmanial and cytotoxic activity of Zataria multiflora," Pharmaceutical Biology, vol. 54, no. 5, 2015.

[37] P. Satyal, S. Shrestha, and W. N. Setzer, "Composition and bioactivities of an (E)- $\beta$-farnesene chemotype of chamomile (Matricaria chamomilla) essential oil from Nepal," Natural Product Communications, vol. 10, no. 8, pp. 1453-1457, 2015.

[38] W. Liu, L. P. Li, J. D. Zhang et al., "Synergistic antifungal effect of glabridin and fluconazole," PLoS ONE, vol. 9, no. 7, Article ID e103442, 2014.

[39] N. C. G. Faria, J. H. Kim, L. A. P. Gonçalves, M. D. L. Martins, K. L. Chan, and B. C. Campbell, "Enhanced activity of antifungal drugs using natural phenolics against yeast strains of Candida and Cryptococcus," Letters in Applied Microbiology, vol. 52, no. 5, pp. 506-513, 2011.

[40] T. C. White, K. A. Marr, and R. A. Bowden, "Clinical, cellular, and molecular factors that contribute to antifungal drug resistance," Clinical Microbiology Reviews, vol. 11, no. 2, pp. 382-402, 1998.

[41] V. T. Andriole, "Current and future antifungal therapy: new targets for antifungal agents," Journal of Antimicrobial Chemotherapy, vol. 44, no. 2, pp. 151-162, 1999.

[42] K. S. De Lira Mota, F. De Oliveira Pereira, W. A. De Oliveira, I. O. Lima, and E. De Oliveira Lima, "Antifungal activity of Thymus vulgaris L. essential oil and its constituent phytochemicals against Rhizopus oryzae: interaction with ergosterol," Molecules, vol. 17, no. 12, pp. 14418-14433, 2012.

[43] A. Khan, A. Ahmad, F. Akhtar et al., "Ocimum sanctum essential oil and its active principles exert their antifungal activity by disrupting ergosterol biosynthesis and membrane integrity," Research in Microbiology, vol. 161, no. 10, pp. 816-823, 2010.

[44] S. B. Rajput and S. Mohan Karuppayil, "Small molecules inhibit growth, viability and ergosterol biosynthesis in Candida albicans," SpringerPlus, vol. 2, no. 1, pp. 1-6, 2013.

[45] O. Zaragoza, R. Garcia-Rodas, J. D. Nosanchuk, M. CuencaEstrella, J. L. Rodríguez-Tudela, and A. Casadevall, "Fungal cell gigantism during mammalian infection," PLoS Pathogens, vol. 6, no. 6, Article ID e1000945, 2010.

[46] R. G. Vitale, V. Pascuccelli, and J. Afeltra, "Influence of capsule size on the in vitro activity of antifungal agents against clinical Cryptococcus neoformans var. grubii strains," Journal of Medical Microbiology, vol. 61, no. 3, pp. 384-388, 2012.

[47] W. S. Alviano, R. R. Mendonça-Filho, D. S. Alviano et al., "Antimicrobial activity of Croton cajucara Benth linalool-rich essential oil on artificial biofilms and planktonic microorganisms," Oral Microbiology and Immunology, vol. 20, no. 2, pp. 101105, 2005.

[48] S. Taweechaisupapong, S. Singhara, P. Lertsatitthanakorn, and W. Khunkitti, "Antimicrobial effects of Boesenbergia pandurata and Piper sarmentosum leaf extracts on planktonic cells and biofilm of oral pathogens," Pakistan Journal of Pharmaceutical Sciences, vol. 23, no. 2, pp. 224-231, 2010. 
[49] S. Thaweboon and B. Thaweboon, "In vitro antimicrobial activity of Ocimum americanum L. essential oil against oral microorganisms," Southeast Asian Journal of Tropical Medicine and Public Health, vol. 40, no. 5, pp. 1025-1033, 2009.

[50] S. Dalleau, E. Cateau, T. Bergès, J.-M. Berjeaud, and C. Imbert, "In vitro activity of terpenes against Candida biofilms," International Journal of Antimicrobial Agents, vol. 31, no. 6, pp. 572-576, 2008. 


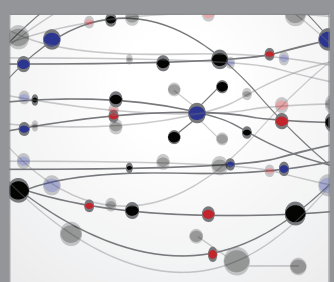

The Scientific World Journal
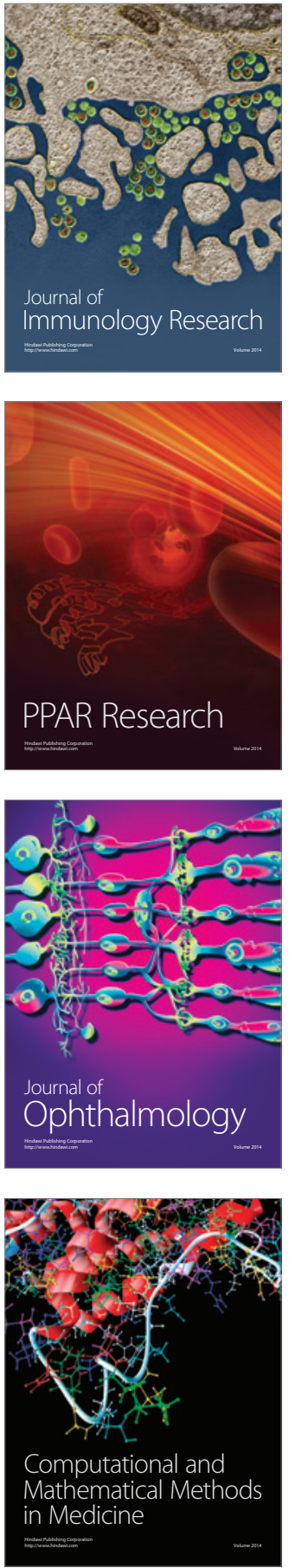

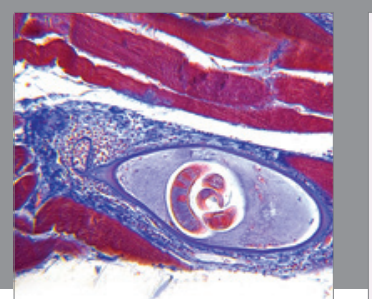

Gastroenterology Research and Practice

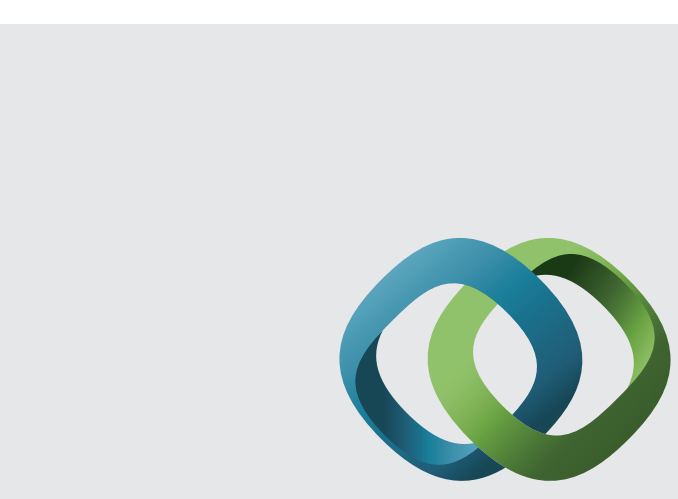

\section{Hindawi}

Submit your manuscripts at

http://www.hindawi.com
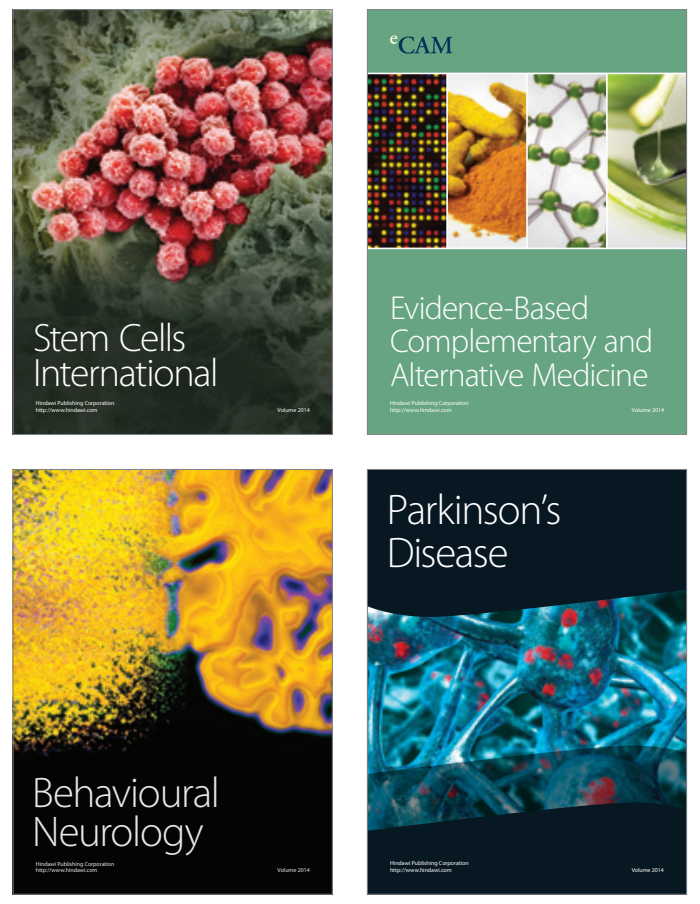
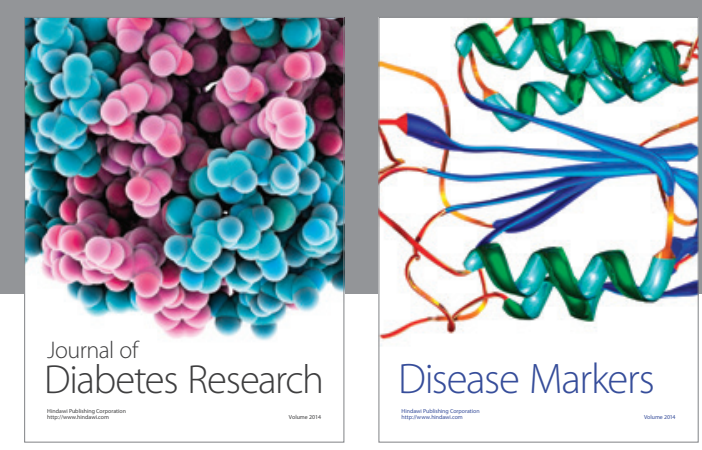

Disease Markers
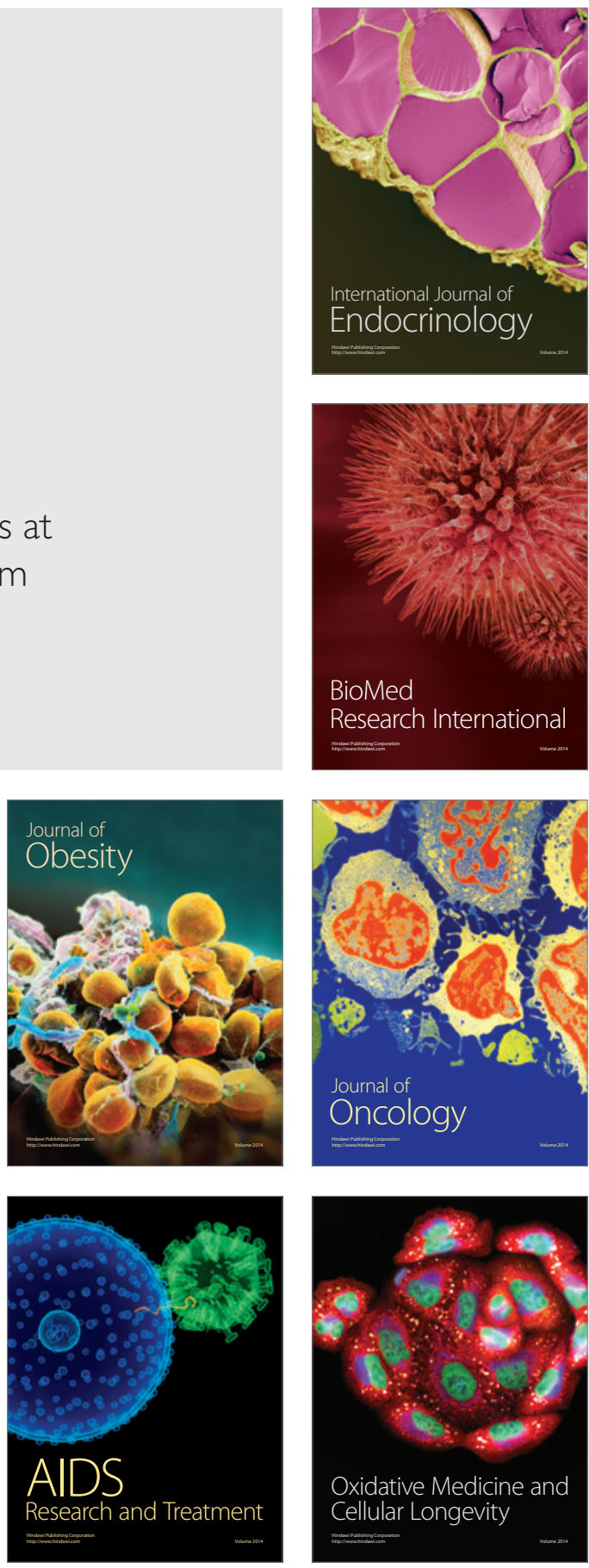